\author{
Aleksandra Jamrozik**, Stanisław Stryczek*, Rafał Wiśniowski*, \\ Andrzej Gonet*, Rafał Wójcik**
}

\title{
AN APPLICATION OF ORGANIC NANOSILICA TO CEMENT SLURRIES BASED ON PORTLAND CEMENT***
}

\section{INTRODUCTION}

A correctly performed cementing job in a borehole depends on the design of the borehole, geologic-reservoir conditions, technical-technological conditions in the boreholes, cementing job itself and also the quality and composition of the applied cement slurry.

More and more attention is nowadays paid to the quality and durability of the applied cement slurries. Apart from appropriate rheological, technological and strength parameters, the slurry should be resistant to the strongly mineralized reservoir waters.

Among the most important criteria of durability of cement slurries applied with the borehole injection methods are $[1,4,6-8,12]$ :

- appropriate phase composition of hardened cement slurry, i.e.:

- possibly lowest portlandite $\left(\mathrm{Ca}(\mathrm{OH})_{2}\right)$ content,

- low in aluminate $\left(\mathrm{C}_{3} \mathrm{~A}\right)$ phase,

- highest possible content of calcium silicate (C-S-H phase),

- microstructure of minimum permeability.

Porous and permeable microstructure of hardened cement slurries is directly responsible for the diffusion of aggressive ions inside the cement sheath. Appropriate phase composition of cement slurries, especially high CSH content is responsible for the change of pore structure in the cement slurry; the number of fine gel pores which are not available for the fluid increases and the number of capillary pores responsible for the transport of corrosive factors inside the cement slurry decreases [2].

\footnotetext{
* AGH University of Science and Technology, Faculty of Drilling, Oil and Gas, Krakow, Poland

** Exalo SA, Center in Zielona Góra, Poland

*** Work realized within statutory research program No. 11.11.190.555 at the Department of Drilling and Geoengineering, Faculty of Drilling, Oil and Gas, AGH University of Science and Technology, Krakow
} 
The use of nanosilica as an additive improving the properties of cement slurries has recently gained popularity. The analysis of literature data reveals that the following factors advantageously influence the microstructure of hardened cement slurries [5]:

- well dispersed nano particles which increase the viscosity of the liquid phase, and so the stability of the dispersion,

- microstructure of lowest possible porosity and lowest possible participation of continuous capillary pores,

- nano particles fill the empty spaces between cement grains as a result of 'free' water immobilization ('filler' effect),

- nano particles favor the formation of amorphous gel C-S-H which has an ordered structure,

- nano- $\mathrm{SiO}_{2}$ participates in the pozzolanic reactions, resulting in the consumption of $\mathrm{Ca}(\mathrm{OH})_{2}$ and formation of an 'additional' $\mathrm{C}-\mathrm{S}-\mathrm{H}$,

- nano particles improve the structure of the aggregates' contact zone, resulting in a better bond between aggregates and cement paste.

Bearing in mind these properties of $\mathrm{nSiO}_{2}$, there were conducted laboratory experiments on the use of organic nanosilica for cement slurries based on Portland cement CEM I 52.5 R.

\section{CHARACTERISTIC OF RESEARCH MATERIAL}

The hydraulic binder used for the slurries was Portland cement CEM I 52.5 R from Cement Plant 'Rejowiec' (59\% Portland clinker and 5\% accessory components). Organic nanosilica products Protectosil WS 808 and Protectosil 851 by Evonic Degussa Polska Sp. $\mathrm{z}$ o. o. were used as additives. Their properties are given in Table 1.

Protectosil WS 808 Oligomeric propyl siliconate/silicate concentrate as water repellent and consolidant for mineral substrates. Clear colorless liquid, approx. 55\% active ingredient, water-based, VOC-free, non-flammable.

Protectosil 851 a blend based on polyvinyl alcohol and silane. White, odor-free powder, water-soluble.

Table 1

Properties of analyzed nanosilica

\begin{tabular}{|l|c|c|c|}
\hline \multicolumn{1}{|c|}{ Properties } & Unit & Protectosil WS 808 & Protectosil 851 \\
\hline Viscosity $\left(20^{\circ} \mathrm{C}\right)$ & $\mathrm{MPa} \cdot \mathrm{s}$ & 10.6 & - \\
\hline Density $\left(20^{\circ} \mathrm{C}\right)$ & $\mathrm{g} / \mathrm{cm}^{3}$ & 1.4 & 1.13 \\
\hline Ignition temperature & ${ }^{\circ} \mathrm{C}$ & 61 & - \\
\hline Boiling temperature & ${ }^{\circ} \mathrm{C}$ & 105 & $10.0-11.0$ \\
\hline $\mathrm{pH}$ & - & $>13\left(25^{\circ} \mathrm{C}\right)$ & $22-24$ \\
\hline $\mathrm{SiO}_{2}$ content & $\% \mathrm{w} / \mathrm{w}$ & 55 & $250-450$ \\
\hline $\mathrm{Bulk}$ density & $\mathrm{kg} / \mathrm{m}^{3}$ & - & - \\
\hline
\end{tabular}




\section{RESEARCH METHODICS}

The laboratory experiments were aimed at evaluating the influence of organic nanosilica on technological and rheological parameters of fresh and hardened cement slurries, their microstructure and phase composition and also permeability of the analyzed slurries. Network water was used as working fluid. The water-cement ratios for the analyzed slurries were; 0.5 and 0.6. nanosilica introduced to the Portland cement in $0.5 \mathrm{wt} . \%$ and $1.0 \mathrm{wt} . \%$ of dry cement. The temperature of cement and working fluid used for the experiments was $20^{\circ} \mathrm{C}\left( \pm 2^{\circ} \mathrm{C}\right)$. The recipes of the analyzed cement slurries are presented in Table 2 .

Table 2

Recipes of analyzed cement slurries

\begin{tabular}{|c|c|c|}
\hline Symbol & Composition of slurry & w/c \\
\hline A & $100 \%$ CEM I 52.5R & 0.5 \\
\hline A1 & 99.5 wt.\% CEM I 52.5R + 0.5 wt.\% Protectosil WS 808 & 0.5 \\
\hline A2 & 99.0 wt.\% CEM I 52.5R + 1.0 wt.\% Protectosil WS 808 & 0.5 \\
\hline A3 & 99.5 wt.\% CEM I 52.5R + 0.5 wt.\% Protectosil 851 & 0.5 \\
\hline A4 & 99.0 wt.\% CEM I 52.5R + 1.0 wt.\% Protectosil 851 & 0.5 \\
\hline B & 100 wt.\% CEM I 52.5R & 0.6 \\
\hline B1 & 99.5 wt.\% CEM I 52.5R + 0.5 wt.\% Protectosil WS 808 & 0.6 \\
\hline B2 & 99.0 wt.\% CEM I 52.5R + 1.0 wt.\% Protectosil WS 808 & 0.6 \\
\hline B3 & 99.5 wt.\% CEM I 52.5R + 0.5 wt.\% Protectosil 851 & 0.6 \\
\hline B4 & 99.0 wt.\% CEM I 52.5R + 1.0 wt.\% Protectosil 851 & 0.6 \\
\hline
\end{tabular}

The laboratory measurements of technologically fresh and hardened cement slurries were conducted on the basis of the following standards:

- PN-EN 197-1: 2002 - Cement. Part 1: Composition, requirements and congruence criteria for common use cements (Cement. Część 1: Skład, wymagania i kryteria zgodności dotyczace cementów powszechnego użytku),

- PN-EN ISO 10426-2: 2006. - Oil and gas industry. Cements and materials for cementing boreholes. Part 2: Analysis of drilling cements (Przemyst naftowy i gazowniczy Cementy i materiały do cementowania otworów wiertniczych. Część 2: Badania cementów wiertniczych),

- PN-EN 196-3+A1: 2011 - Methods of analyzing cement. Part 3: Determining time of binding and volume stability (Metody badania cementu. Część 3: Oznaczanie czasów wiązania $i$ stałości objętości),

- PN-EN 196-1: 2006 - Methods of analyzing cement. Part 1: Determining strength (Metody badania cementu. Część 1: Oznaczanie wytrzymałości).

The laboratory analyses were performed for the following parameters:

- for fresh cement slurries:

- density - with the use of Baroid weight,

- sedimentation with the use of measuring cylinder,

- filtration with the use of Baroid filtration press, 
- rheological parameters with the use of Chan 35 API Viscometer,

- time of binding with the use of Vicat apparatus,

- for hardened cement slurries:

- compressive and bending strength after 7, 14, 21 and 28 days of storing in wet conditions at a temperature of $20^{\circ} \mathrm{C}\left( \pm 2^{\circ} \mathrm{C}\right)$.

Additional analyses were performed, i.e. measurement of permeability of hardened cement slurries and microstructural analysis of slurries maturing in naturally wet conditions at a temperature of $20^{\circ} \mathrm{C}\left( \pm 2^{\circ} \mathrm{C}\right)$.

The permeability of cement slurries was analyzed according to the method described in the paper [3].

The quantity of filtered difference of pressures, according to Darcy law:

$$
Q=\frac{k \cdot \Delta p}{\mu \cdot L} \cdot F
$$

After transforming the equation we can calculate the filtration coefficient from:

where:

$$
k=\frac{Q \cdot L \cdot \mu}{F \cdot \Delta p}
$$

$k$ - coefficient of permeability of hardened cement slurry $\left[\mathrm{m}^{2}\right]$,

$Q$ - flow rate of a volume of fluid $\left[\mathrm{m}^{3} / \mathrm{s}\right]$,

$L$ - length of sample [m],

$F$ - surface area of sample $\left[\mathrm{m}^{2}\right]$,

$\mu$ - coefficient of dynamic viscosity of filtrating fluid at the measurement temperature $[\mathrm{Pa} \cdot \mathrm{s}]$,

$\Delta p$ - difference between entry and atmospheric pressures [Pa].

The temperature of the test was $20^{\circ} \mathrm{C}$, whereas the difference of pressures for each sample was $5 \mathrm{MPa}$. The measurement time equaled to $2 \mathrm{hrs}$.

The microstructural analysis of hardened cement slurries was performed with the use of Nova NanoSEM 200 equipped with a unit for elemental analysis in microareas (SEM-EDS) EDAX. The samples were covered with carbon and analyzed in high vacuum conditions. Magnification of $100 \div 10,000 \times$ was used during observations. The elemental analysis in microareas allows for identifying chemical composition of samples at a given point.

\section{RESULTS OF EXPERIMENTS AND DISCUSSION}

\section{Technological parameters of cement slurries with organic nanosilica additives}

The results of analyses of technological parameters of fresh cement slurries are presented in Table 3.

The analysis of the obtained results reveals that nanosilica additives stabilize mineral dispersive systems, i.e. cement slurries, concurrently limiting their filtration, which seems particularly useful when sealing the rock mass. At the same time the addition of $1.0 \mathrm{wt} . \%$ of Protectosil WS 808 reduces filtration much more effectively.

Plots representing times of bonding of analyzed cement slurries are presented in Figures $1-2$. 
Table 3

Technological parameters of analyzed cement slurries

\begin{tabular}{|c|c|c|c|c|}
\hline Symbol & w/c & Density $\left[\mathrm{kg} / \mathrm{m}^{3}\right]$ & Filtration $\left[\mathrm{cm}^{3} / \mathrm{s}\right]$ & Sedimentation $[\%]$ \\
\hline A & 0.5 & 1.81 & $52 / 42$ & 2.4 \\
\hline A1 & 0.5 & 1.81 & $82 / 62$ & 0.6 \\
\hline A2 & 0.5 & 1.82 & $53 / 47$ & 0.4 \\
\hline A3 & 0.5 & 1.81 & $76 / 46$ & 0.8 \\
\hline A4 & 0.5 & 1.81 & $69 / 62$ & 0.6 \\
\hline B & 0.6 & 1.72 & $90 / 44$ & 3.0 \\
\hline B1 & 0.6 & 1.72 & $92 / 55$ & 0.7 \\
\hline B2 & 0.6 & 1.72 & $85 / 63$ & 0.3 \\
\hline B3 & 0.6 & 1.72 & $89 / 65$ & 0.8 \\
\hline B4 & 0.6 & 1.71 & $93 / 52$ & 0.4 \\
\hline
\end{tabular}

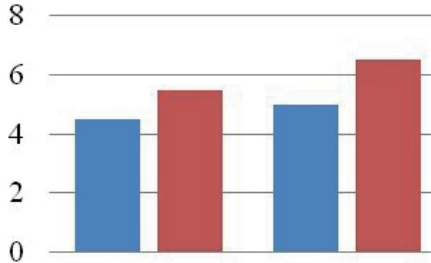

A

A1

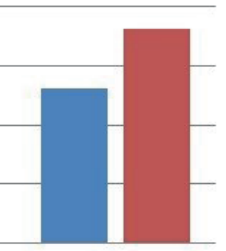

A2
10

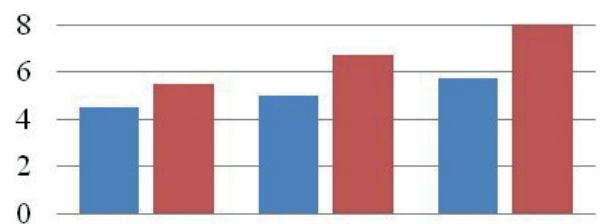

A
A3
A4

Beginning of bonding End of bonding

Fig. 1. Change of time of bonding of cement slurries where $\mathrm{w} / \mathrm{c}=0.5$

A - reference slurry, A1 - slurry containing 0.5 wt.\% of Protectosil WS 808, A2 - slurry containing 1 wt. $\%$ of Protectosil WS 808, A3 - slurry containing 0.5 wt. $\%$ of Protectosil 851 , A4 - slurry containing $1 \mathrm{wt} . \%$ of Protectosil 851

15

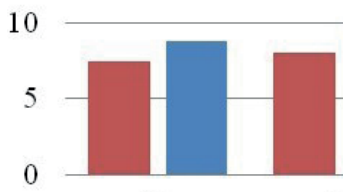

B

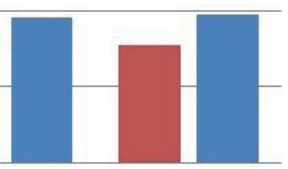

B1
15

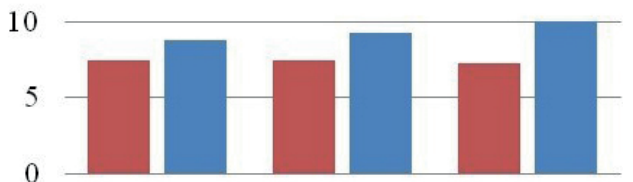

B
B4

a Beginning of bonding $\quad$ End of bonding

Fig. 2. Change of time of bonding of cement slurries where $w / c=0.6$

B - reference slurry, B1 - slurry containing 0.5 wt.\% of Protectosil WS 808, B2 - slurry containing 1 wt. $\%$ of Protectosil WS 808, B3 - slurry containing 0.5 wt.\% of Protectosil 851, B4 - slurry containing 1 wt. $\%$ of Protectosil 851

The data presented in Figures 1-2 show that the addition of organic nanosilica delays the hydration of cement, which manifests itself in elongated time of bonding of cement slurries based on Portland cement. 
The addition of $1.0 \mathrm{wt} . \%$ of Protectosil 851 reduces filtration most effectively. The time of bonding for cement w/c $=0.6$ containing $1 \mathrm{wt} . \%$ of Protectosil 851 was elongated by $1 \mathrm{~h}$ 45 minutes as compared to the reference slurry of the same w/c ratio (Fig. 2). The bonding time of cement slurries containing Protectosil WS 808 was the same, regardless the $\mathrm{w} / \mathrm{c}$ ratio and equaled to $1 \mathrm{~h} 30$ minutes for a slurry containing 0.5 wt.\% of Protectosil WS 808 and $2 \mathrm{hrs}$ for slurries containing $1 \mathrm{wt} . \%$ of Protectosil WS 808.

\section{Rheological parameters of cement slurries containing organic nanosilica}

Calculation of rheological parameters and selection of rheological model of analyzed cement slurries were performed on the basis of a numerical program Rheo Solution [9-11].

The results illustrating the influence of nanosilica on rheological properties of the cement slurries based on Portland cement CEM I 52.5 R with organic nanosilica admixtures are presented in Table 4.

\section{Table 4}

Rheological parameters of cement slurries on the basis of Portland cement with silica organic compounds

\begin{tabular}{|c|c|c|c|c|}
\hline $\begin{array}{l}\text { Composition } \\
\text { of slurry }\end{array}$ & \multicolumn{2}{|r|}{ Rheological parameters } & $\begin{array}{l}\text { Result for } \\
\mathrm{w} / \mathrm{c}=0.5\end{array}$ & $\begin{array}{l}\text { Result for } \\
\mathrm{w} / \mathrm{c}=0.6\end{array}$ \\
\hline \multirow{4}{*}{$\begin{array}{c}100 \% \text { CEM } \\
\text { I } 52.5 \mathrm{R}\end{array}$} & \multirow{3}{*}{$\begin{array}{l}\text { Herschel- } \\
\text {-Bulkley } \\
\text { model }\end{array}$} & Yield point $[\mathrm{Pa}]$ & 1.108 & 2.389 \\
\hline & & Consistency coefficient $k_{\mathrm{HB}}\left[\mathrm{Pa} \cdot \mathrm{s}^{\mathrm{n}}\right]$ & 2.334 & 1.266 \\
\hline & & Shape coefficient $n[-]$ & 0.583 & 0.520 \\
\hline & \multicolumn{2}{|c|}{ Apparent viscosity for $1022.04\left[\mathrm{~s}^{-1}\right][\mathrm{Pa} \cdot \mathrm{s}]$} & 0.131 & 0.049 \\
\hline \multirow{4}{*}{$\begin{array}{c}0.5 \text { wt. } \% \\
\text { Protectosil } \\
\text { WS } 808\end{array}$} & \multirow{3}{*}{$\begin{array}{l}\text { Herschel- } \\
\text {-Bulkley } \\
\text { model }\end{array}$} & Yield point $[\mathrm{Pa}]$ & 3.954 & 3.967 \\
\hline & & Consistency coefficient $k_{\mathrm{HB}}\left[\mathrm{Pa} \cdot \mathrm{s}^{\mathrm{n}}\right]$ & 1.393 & 0.354 \\
\hline & & Shape coefficient $n[-]$ & 0.697 & 0.800 \\
\hline & \multicolumn{2}{|c|}{ Apparent viscosity for $1022.04\left[\mathrm{~s}^{-1}\right][\mathrm{Pa} \cdot \mathrm{s}]$} & 0.175 & 0.094 \\
\hline \multirow{4}{*}{$\begin{array}{l}1.0 \text { wt. } \% \\
\text { Protectosil } \\
\text { WS } 808\end{array}$} & \multirow{3}{*}{$\begin{array}{l}\text { Herschel- } \\
\text {-Bulkley } \\
\text { model }\end{array}$} & Yield point $[\mathrm{Pa}]$ & 4.007 & 2.768 \\
\hline & & Consistency coefficient $k_{\mathrm{HB}}\left[\mathrm{Pa} \cdot \mathrm{s}^{\mathrm{n}}\right]$ & 1.095 & 0.190 \\
\hline & & Shape coefficient $n[-]$ & 0.723 & 0.776 \\
\hline & \multicolumn{2}{|c|}{ Apparent viscosity for $1022.04\left[\mathrm{~s}^{-1}\right][\mathrm{Pa} \cdot \mathrm{s}]$} & 0.166 & 0.043 \\
\hline \multirow{4}{*}{$\begin{array}{l}0.5 \text { wt. } \% \\
\text { Protectosil } \\
\quad 851\end{array}$} & \multirow{3}{*}{$\begin{array}{l}\text { Herschel- } \\
\text {-Bulkley } \\
\text { model }\end{array}$} & Yield point $[\mathrm{Pa}]$ & 4.705 & 0.718 \\
\hline & & Consistency coefficient $k_{\mathrm{HB}}\left[\mathrm{Pa} \cdot \mathrm{s}^{\mathrm{n}}\right]$ & 1.348 & 2.277 \\
\hline & & Shape coefficient $n[-]$ & 0.703 & 0.519 \\
\hline & \multicolumn{2}{|c|}{ Apparent viscosity for $1022.04\left[\mathrm{~s}^{-1}\right][\mathrm{Pa} \cdot \mathrm{s}]$} & 0.175 & 0.080 \\
\hline \multirow{4}{*}{$\begin{array}{c}1.0 \text { wt. } \% \\
\text { Protectosil } \\
851\end{array}$} & \multirow{3}{*}{$\begin{array}{l}\text { Herschel- } \\
\text {-Bulkley } \\
\text { model }\end{array}$} & Yield point $[\mathrm{Pa}]$ & 4.691 & 1.962 \\
\hline & & Consistency coefficient $k_{\mathrm{HB}}\left[\mathrm{Pa} \cdot \mathrm{s}^{\mathrm{n}}\right]$ & 2.318 & 2.361 \\
\hline & & Shape coefficient $n[-]$ & 0.623 & 0.518 \\
\hline & \multicolumn{2}{|c|}{ Apparent viscosity for $1022.04\left[\mathrm{~s}^{-1}\right][\mathrm{Pa} \cdot \mathrm{s}]$} & 0.175 & 0.084 \\
\hline
\end{tabular}

The analysis of the calculated values of correlation coefficient for particular cement slurries reveal that all analyzed cement slurries have properties of shear-diluted non-Newtonian fluids, described with the Herschel-Bulkley model (Tab. 4). Organic nanosilica do not change the character of flow of the analyzed cement slurry. 
The addition of organic nanosilica causes that gel structures are formed in the analyzed slurries under the influence of operation of hydrogen bondings. However, these structures are not durable and can be easily destroyed under the influence of the shear rate. In the low shear rate range the apparent viscosity of cement slurry containing organic nanosilica is higher. Higher shear rates make the apparent viscosities of cement slurries practically equal, which is important from the point of view of slurry pumpability.

\section{Strength parameters of hardened cement slurries containing organic nanosilica}

The plots illustrating the influence of Protectosil WS 808 and Protectosil 851 on the strength parameters of cement slurries based on Portland cement CEM I 52.5 R and network water are presented in Figures 3-6.
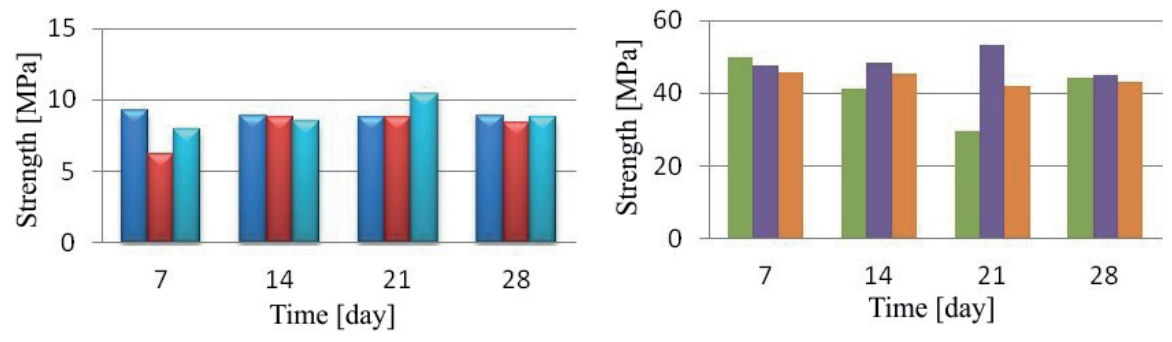

bending strength (slurry A)

- compressive strength (slurry A)

$\square$ bending strength (slurry A1)

compressive strength (slurry A1)

$\square$ bending strength (slurry A2)

a compressive strength (slurry A2)

Fig. 3. Changes of compressive and bending strength of slurries containing Protectosil WS 808 at w/c 0.5

A - reference slurry, A 1 - slurry containing 0.5 wt.\% of Protectosil WS 808,

A2 - slurry containing $1 \mathrm{wt} . \%$ of Protectosil WS 808
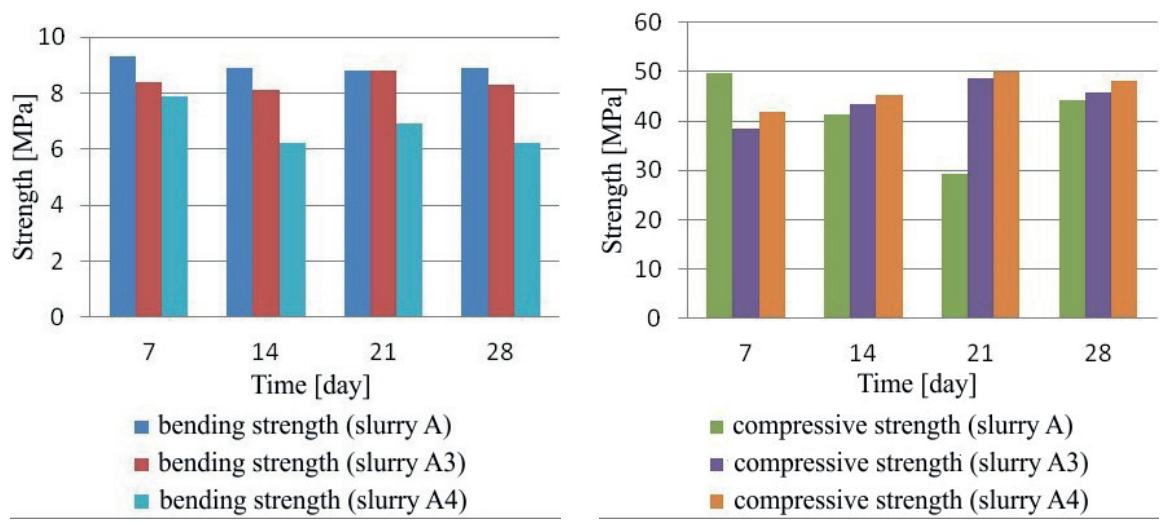

Fig. 4. Changes of compressive and bending strength of slurries containing Protectosil 851 at w/c 0.5 A - reference slurry, A3 - slurry containing 0.5 wt.\% of Protectosil 851, A4 - slurry containing $1 \mathrm{wt} . \%$ of Protectosil 851 


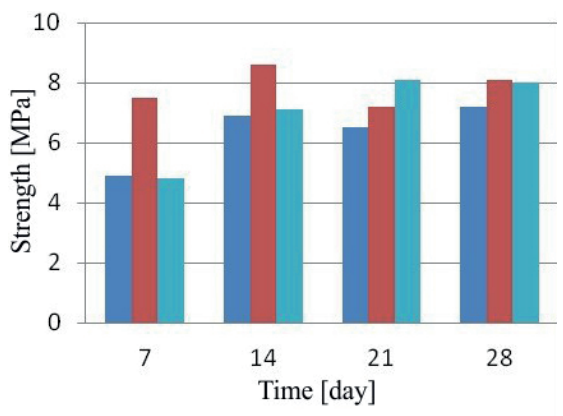

- bending strength (slurry B)

- bending strength (slurry B1)

bending strength (slurry B2)

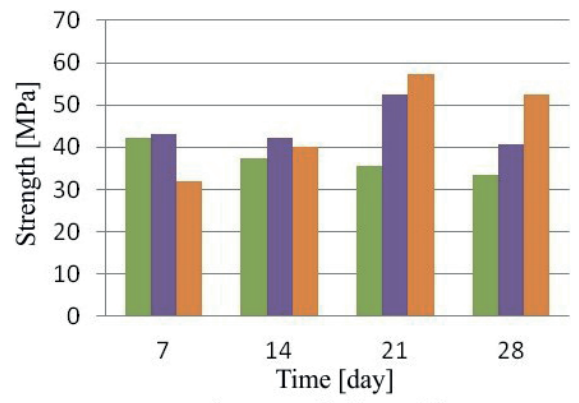

a compressive strength (slurry B)

compressive strength (slurry B1)

- compressive strength (slurry B2)

Fig. 5. Changes of compressive and bending strength of slurries containing Protectosil WS 808 at w/c 0.6. B - reference slurry B1 - slurry containing 0.5 wt.\% of Protectosil WS 808, B2 - slurry containing $1 \mathrm{wt} . \%$ of Protectosil WS 808

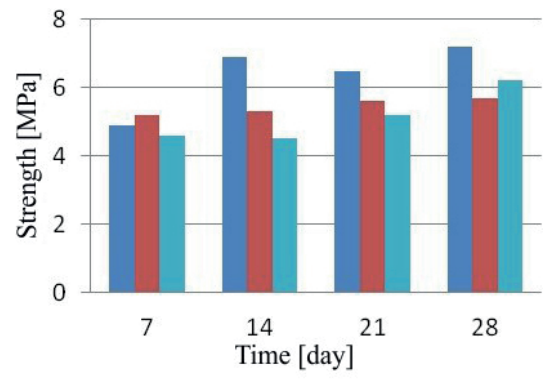

bending strength (slurry B)

- bending strength (slurry B3)

- bending strength (slurry B4)

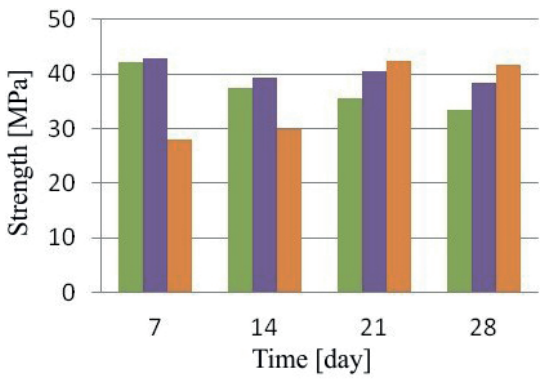

- compressive strength (slurry B)

- compressive strength (slurry B3)

- compressive strength (slurry B4)

Fig. 6. Changes of compressive and bending strength of slurries containing Protectosil 851 at w/c 0.6 B - reference slurry, B3 - slurry containing 0.5 wt.\% of Protectosil 851 , B4 - slurry containing 1 wt.\% of Protectosil 851

The analyzed reference slurries (no additives) have high early strength (after 7 days). This effect is connected with the properties of Portland cement. The addition of a solution of organic silica (Protectosil WS 808) results in the lowering of strength parameters at the initial stage of maturation of the slurry. After 28 days the strength parameters are on a slightly higher level than the reference one. After adding Protectosil 851 to the cement slurry the compressive strength increases after 28 days but also decreases the bending strength after 28 days as compared to the reference slurry. 


\section{Analysis of permeability of fluids with organic nanosilica}

The results of analyses of permeability of hardened slurries at w/c 0.5 and 0.6 with Protectosil WS 808 and Protectosil 851 are presented in Figures 7-8.
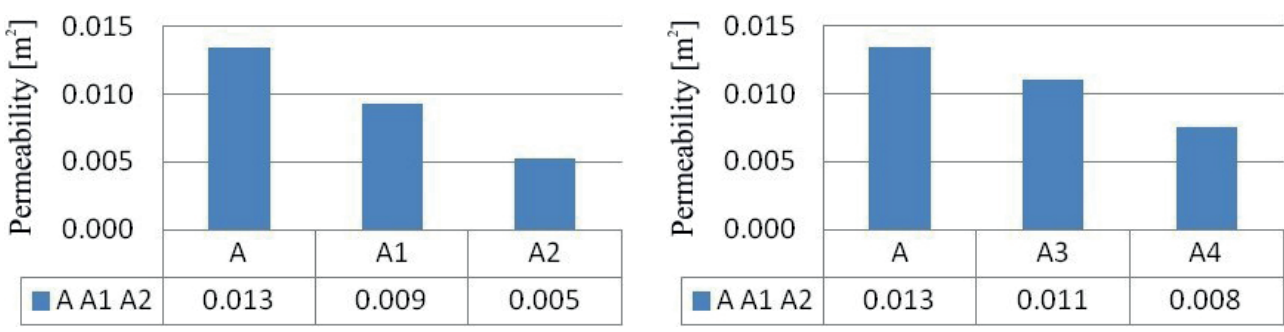

Fig. 7. Changes of permeability of slurries at w/c 0.5 with Protectosil WS 808 A - reference slurry, A 1 - slurry containing 0.5 wt.\% of Protectosil WS 808 , A2 - slurry containing $1 \mathrm{wt} . \%$ of Protectosil WS 808, A3 - slurry containing $0.5 \mathrm{wt} . \%$ of Protectosil 851 , A4 - slurry containing $1 \mathrm{wt} . \%$ of Protectosil 851
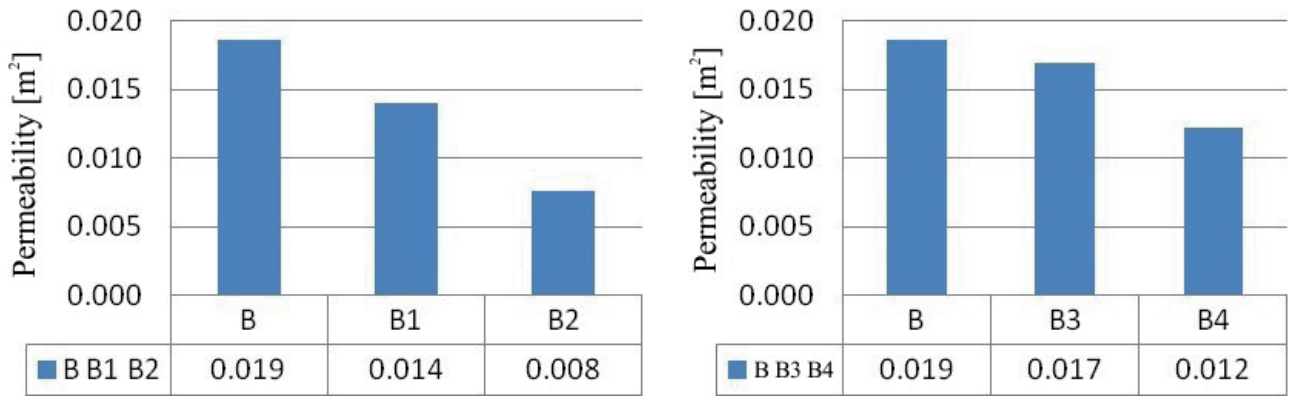

Fig. 8. Changes of permeability of slurries at w/c 0.6 with Protectosil WS 808 B - reference slurry, B1 - slurry containing 0.5 wt.\% of Protectosil WS 808 , B2 - slurry containing $1 \mathrm{wt} . \%$ of Protectosil WS 808 , B3 - slurry containing 0.5 wt.\% of Protectosil 851 , B4 - slurry containing $1 \mathrm{wt} . \%$ of Protectosil

The analysis of the data presented in Figures $7-8$ reveals that the biggest permeability can be observed for reference slurries (no additives). The addition of organic nanosilica lowers down the permeability. This effect is most prominent after Protectosil WS 808 is added. For a slurry with w/c $=0.5$ containing $1 \mathrm{wt} . \%$ of Protectosil WS 808 the permeability decreases by over $60 \%$.

\section{Microstructural analysis of hardened cement slurries with organic nanosilica}

The microstructural and elemental analysis in microareas of hardened cement slurries having w/c $=0.5$ with and without admixtures of 0.5 wt. $\%$ of Protectosil WS 808 and 0.5 wt.\% of Protectosil 851 are presented in Figures 9-11. 

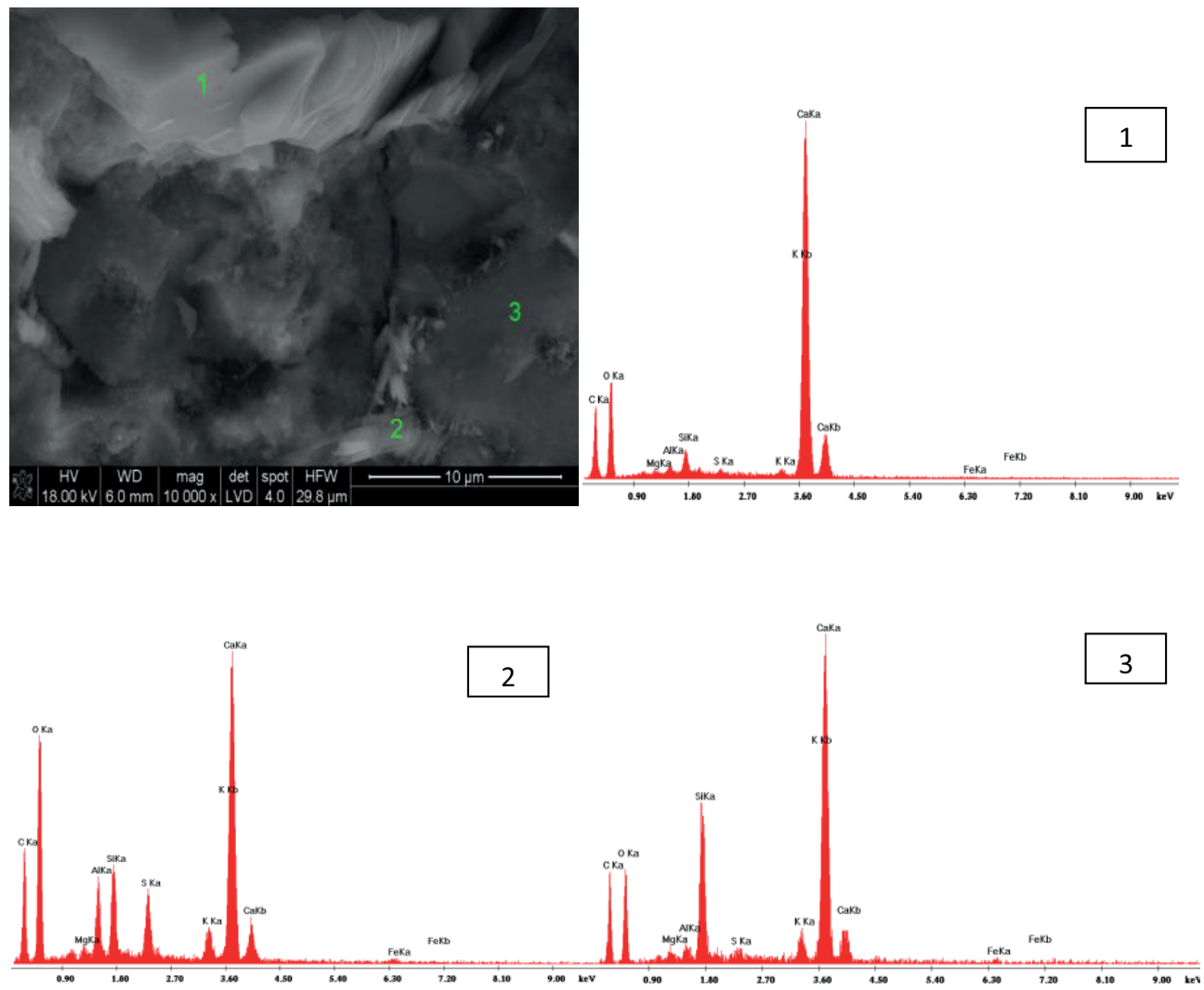

Fig. 9. Microstructure of hardened cement slurry based on Portland cement CEM I 52.5R Visible hydration products in the form of $\mathrm{C}-\mathrm{S}-\mathrm{H}$ phase modified with aluminum, magnesium and sulfur ions, forming intergrowths with portlandite $\mathrm{Ca}(\mathrm{OH})_{2}$ and products of its carbonation with calcite (point 1). Elemental analysis in a microarea at point 2 also proves the presence of $\mathrm{C}-\mathrm{S}-\mathrm{H}$ phase forming intergrowths with a small quantity of calcite (point 3 ).

Numerous pores and microfractures are also visible. 10,000× magnification

The results of microstructural analyses of analyzed cement slurries show that the addition of organic nanosilica, especially Protectosil WS 808 affects the formation of additional amount of C-S-H phase. The produced structures of hardened cement slurries containing organic nanosilica have better crystallized form of $\mathrm{C}-\mathrm{S}-\mathrm{H}$ than in the case of hardened slurries without additives. In the case of a slurry without organic silica additives the $\mathrm{C}-\mathrm{S}-\mathrm{H}$ phase has a colloidal form and forms intergrowths with portlandite and its carbonation.

The microstructural analysis confirms the results of permeability tests, i.e. the porosity decreases with the growth of organic silica compounds, as can be seen on the SEM images. 

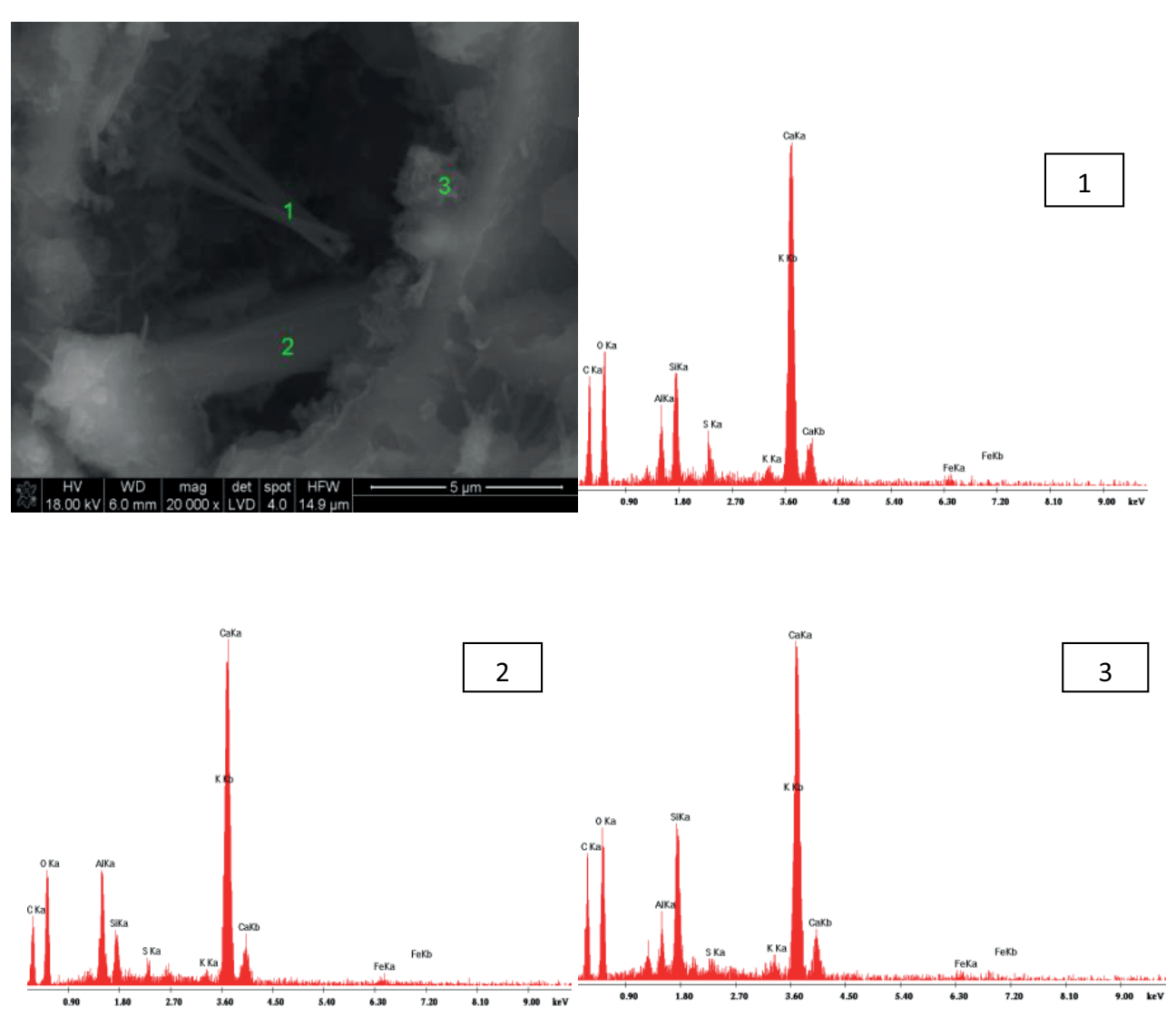

Fig. 10. Photogram illustrating microstructure of hardened slurry $\mathrm{w} / \mathrm{c}=0.5$ based on Portland cement CEM I 52.5R containing $0.5 \mathrm{wt} . \%$ of Protectosil WS 808 . Visible products of cement hydration form intergrowths mainly with $\mathrm{C}-\mathrm{S}-\mathrm{H}$ phase. The $\mathrm{C}-\mathrm{S}-\mathrm{H}$ phase with increased quantity of carbon and aluminum ions is visible at point 1 . The elemental analysis in microarea is presented at point 2 also proves the existence of $\mathrm{C}-\mathrm{S}-\mathrm{H}$ phase which forms intergrowths with calcite (point 3). Ettringite also appears there. $20,000 \times$ magnification
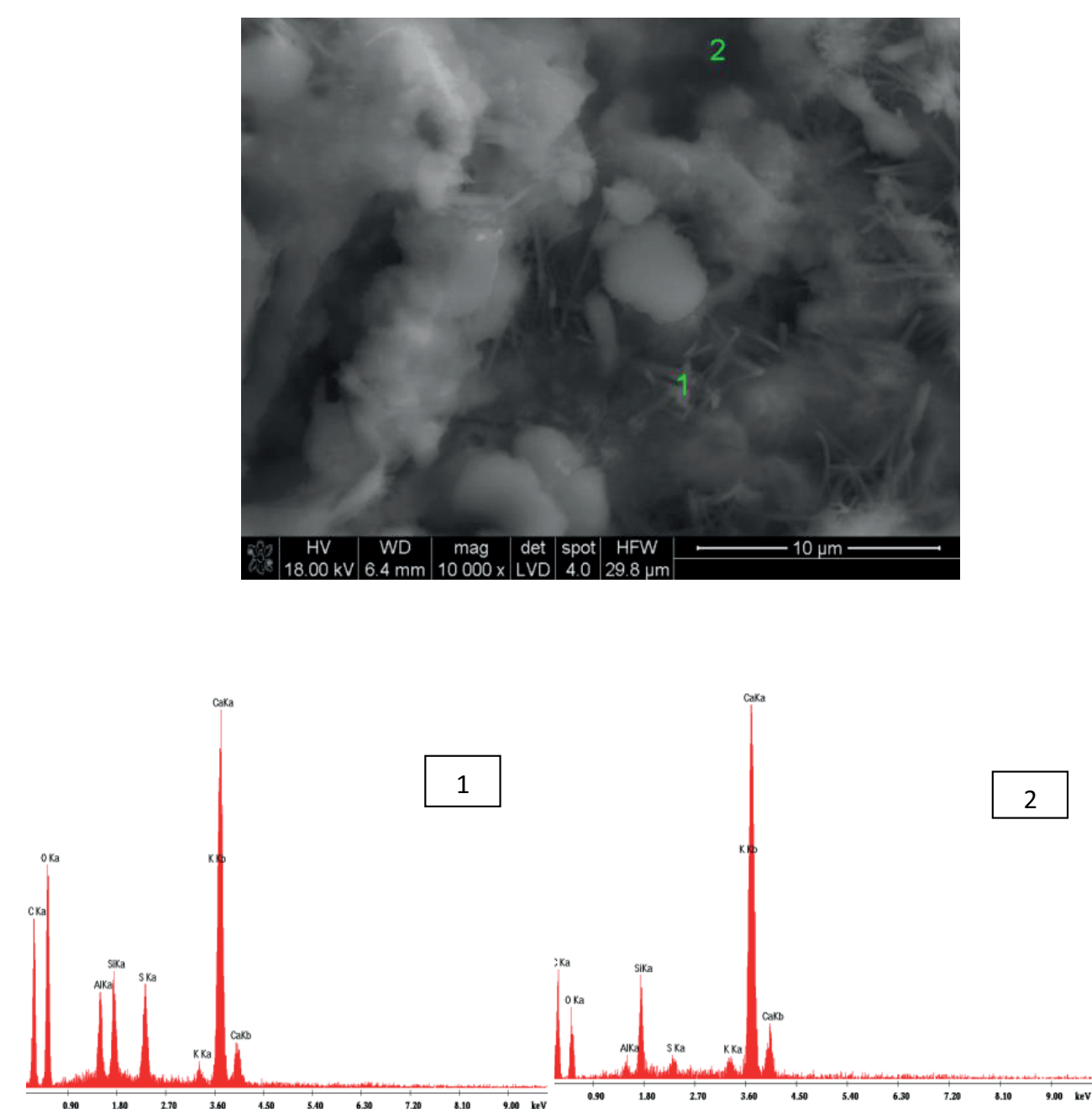

Fig. 11. Microstructure of hardened slurry w/c 0.5 based on Portland cement CEM I 52.5R containing 0.5 wt.\% of Protectosil 851. Fibrous stripes of $\mathrm{C}-\mathrm{S}-\mathrm{H}$ phase dominate forming intergrowths with calcite and dolomite (point 1) A small amount of ettringite and non-hydrated C-S-H phase is visible at point $2(10,000 \times)$ magnification 


\section{CONCLUSIONS}

Organic nanosilica compounds Protectosil WS 808 and Protectosil 851 generate additional quantities of $\mathrm{C}-\mathrm{S}-\mathrm{H}$ phase. The microstructural analyses (SEM) of hardened cement slurries with above mentioned additives show that they have definitely less pores and cracks than the reference slurries.

The permeability analyses of cement slurry containing organic nanosilica additives show that the analyzed structures of hardened cement slurries is considerably sealed. The addition of 1 wt. $\%$ of Protectosil WS 808 lowers the permeability of cement slurry by about $60 \%$.

Organic nanosilica Protectosil WS 808 and Protectosil 851 are compatible and are easily homogenized with cement slurries. Moreover they limit filtration and sedimentation of fresh cement slurries.

The analyzed nanosilica Protectosil WS 808 and Protectosil 851 play the joint function of fillers, dispersants, puzzolanic additives. Thanks to them cement slurries gain a hydropobic character.

The sealing technologies can be oriented to nano-slurries with emphasis on nanosilica as additives.

\section{REFERENCES}

[1] Choolaei M., Rashidi A.M., Mehdi Ardjmand M., Yadegari A., Soltanian H.: The effect of nanosilica on the physical properties of oil well cement. Materials Science and Engineering A, vol. 538, 2012, pp. 288-294.

[2] Giergiczny Z. (ed.): Cement, kruszywa, beton. Rodzaje, właściwości, zastosowanie. Górażdze Cement, Chorula 2015.

[3] Hendel J., Złotkowski A., Stryczek S.: Model stanowiska laboratoryjnego przeznaczonego do pomiarów przepuszczalności stwardniałego zaczynu uszczelniajacego, zbudowany w oparciu o dynamiczna prase filtracyjna HTHP. Wiertnictwo, Nafta, Gaz, vol. 28 , no. 4, 2011.

[4] Jupe A.C., Wilkinson A.P., Luke K., Funkhouser G.P.: Class H Oil well cement hydration at elevated temperature in the presence of retarding agents: An in situ high-energy X-ray diffraction study. Industrial Engineering Chemical Research, vol. 44, 2007, pp. 5579-5584.

[5] Sobolev K., Flores I., Hermosillo R., Torres-Martínez L.M.: Nanomaterials And Nanotechnology For High-Performance Cement Composites. Proceedings of ACI Session on "Nanotechnology of Concrete recent Development and Future Prospectives", November 7, 2006, Denver, USA.

[6] Stryczek S., Gonet A., Wiśniowski R.: Wpływ temperatury na właściwości technologiczne zaczynów uszczelniajacych stosowanych do prac geoinżynieryjnych. Wiertnictwo, Nafta, Gaz, vol. 24, no. 1, 2007.

[7] Stryczek S., Brylicki W., Wiśniowski R.: Zaczyny uszczelniające nowej generacji o wysokiej trwałości. Wiertnictwo, Nafta, Gaz, vol. 23, no. 1, 2006. 
[8] Stryczek S., Brylicki W., Rzepka M.: Badania mikrostruktury stwardniałych zaczynów cementowych stosowanych do uszczelniania gtębokich otworów wiertniczych. Wiertnictwo, Nafta, Gaz, vol. 23, no. 1, 2006.

[9] Wiśniowski R.: Metodyka określania modelu reologicznego cieczy wiertniczej. Wiertnictwo, Nafta, Gaz, vol. 18, no. 1, 2001.

[10] Wiśniowski R., Skrzypaszek K.: Analiza modeli reologicznych stosowanych w technologiach inżynierskich. Wiertnictwo, Nafta, Gaz, vol. 23, no. 1, 2006.

[11] Wiśniowski R., Skrzypaszek K.: Komputerowe wspomaganie wyznaczania modelu reologicznego cieczy - program Flow-fluid Coef. Nowoczesne Techniki i Technologie Bezwykopowe, no. 2-3, 2001.

[12] Wójcik R.: Wpływ organicznej krzemionki na właściwości zaczynów cementowych. Akademia Górniczo-Hutnicza im. S. Staszica, Kraków 2012 [materiały niepublikowane $\mathrm{WWNiG]}$. 